\title{
THE INFLUENCE OF ECO-AIRPORT AND MALL-AIRPORT CONCEPTS AND CULTURAL DISPLAY OF EAST BORNEO ON VISITORS' SATISFACTION AT SULTAN AJI MUHAMMAD SULAIMAN AIRPORT BALIKPAPAN
}

\author{
Saida Zainurossalamia Z.A. ${ }^{*}$, Heksarini Ariesta, Sudarsono Sarju \\ Faculty of Economics and Business, Mulawarman University, Indonesia \\ *E-mail: saida.zainurossalamia.za@feb.unmul.ac.id
}

\begin{abstract}
This research aimed to analyze the influence of eco-airport and mall-airport concepts and cultural display of East Borneo on visitors' satisfaction at Sultan Aji Muhammad Sulaiman Airport Balikpapan. The analysis tool was Smart-PLS 3.0 and the research method was quantitative method of path analysis. The result of the research showed that eco-airport and mall-airport concepts and cultural display of East Borneo had positive and significant influence on visitors' satisfaction at Sultan Aji Muhammad Sulaiman Airport Balikpapan with the contribution of R-square value $78,3 \%$.
\end{abstract}

\section{KEY WORDS}

Eco-airport, mall-airport, display, visitor, satisfaction.

Airport or aerodrome is a facility where airplanes can take off and land, (Kazda and Caves, 2010). The simplest airport has at least a runway but large airports are usually equipped with other various facilities, both for service carriers and for its users, (De Neufville, 2016). According to Annex 14 of the ICAO (International Civil Aviation Organization) airport is a particular area of land or water (including buildings, installations and equipment) that is intended entirely or partially for the arrival, departure and airplane movement (Caves 1997).

Sultan Aji Muhammad Sulaiman Airport is the new name of Sepinggan Airport Balikpapan. The use of Sultan Aji Muhammad Sulaiman Airport name begins on September 15, 2014 or since the opening of Sepinggan Airport's new terminal. Sultan Aji Muhammad Sulaiman Airport Balikpapan is the 4th largest airport of 13 airports managed by PT. Angkasa Pura I or Angkasa Pura Airport, (Savitri, 2017). Since the inauguration of the new name of Sultan Aji Muhammad Sulaiman Airport, previously with the name of Sepinggan Airport, Sultan Aji Muhammad Sulaiman Airport has been awarded in various categories every year, not only the domestic award but also the foreign award. In term of the award that is obtained by Sultan Aji Muhammad Sulaiman Airport Balikpapan, it obtains the category of the best airport, grandest airport, and the airport with the best service that provides satisfaction for visitors.

Customer satisfaction is the feeling of pleasure or disappointment of a person after comparing the performance of the product to the expected performance, (Woodruff and Gardial, 1996). Another opinion suggests that customer satisfaction is the customer's feelings to one type of service he/ she gets, (Hansemark and Albinsson, 2004). Buchari (2007) stated that customer satisfaction factors are the situation experienced by customer and can trigger customer emotional. One of the factors that can affect consumer's emotion is creating a marketing atmosphere or so-called store atmosphere, (Grewal et al., 2003). According to Buchari (2007), it focuses on environmental design through visual communication, lighting, color, music, and smell to stimulate customer's perceptual and emotional responses and finally influence purchasing behavior.

According to airport magazine in 2015, it explained that Sultan Aji Muhammad Sulaiman Airport Balikpapan brings the concept of mall in the airport (mall-airport) and also implements eco-airport concept applied in the design of airport buildings or airport atmosphere. The greenhouse effect reflects an eco-friendly place because it is efficient for lighting or electricity. In addition, the artificial forest in the airport allows the coolness in the airport. In term of entertainment, the visitors or passengers will also be facilitated with mall- 
airport concept that provides shopping facilities with comfortable layout. Moreover, when the visitors or passengers visit Sultan Aji Muhammad Sulaiman Airport Balikpapan the will find introduction and description about cultural values of East Borneo including black orchid poster of Borneo, honey bear picture, picture of traditional dance and clothes of Dayak, picture of orang utan, picture of hornbill, and the introduction of other East Borneo cultural values which are promoted in the airport area through the existing displays.

Reviewing from the existing theory, eco-airport and mall-airport concepts and cultural display of East Borneo are contained in the theory of store atmosphere. Therefore, the researchers were willing to test the application of store atmosphere elements within ecoairport and mall-airport concepts and cultural display of East Borneo to the visitor satisfaction of the airport to find out the phenomenon causing Sultan Aji Muhammad Sulaiman Airport Balikpapan receives national and international awards frequently.

This research objectives are: (1) to know the influence of eco-airport concept at Sultan Aji Muhammad Sulaiman Airport Balikpapan on visitor satisfaction; (2) to know the influence of mall-airport concept at Sultan Aji Muhammad Sulaiman Airport Balikpapan on visitor satisfaction; and (3) to know the influence of cultural display of East Borneo at Sultan Aji Muhammad Sulaiman Airport Balikpapan on visitor satisfaction.

\section{LITERATURE REVIEW}

Description of PT Angkasa Pura I. PT Angkasa Pura I (Persero) or also known as Angkasa Pura Airport is a pioneer of airport commercial exploitation in Indonesia since 1962. When President Soekarno returned from the United States, he affirmed his expectation to the Minister of Transportation and Minister of Public Works for Indonesian airports to be equivalent to the airports of developed countries. Currently, Angkasa Pura Airport manages 13 (thirteen) airports in the central and eastern regions of Indonesia as can be seen in Table 1.

Table 1 - List of airports managed by Angkasa Pura Airport

\begin{tabular}{|c|c|c|}
\hline No. & Airport Name & Location \\
\hline 1 & I Gusti Ngurah Rai Airport & Denpasar \\
\hline 2 & Juanda Airport & Surabaya \\
\hline 3 & Sultan Hasanuddin Airport & Makassar \\
\hline 4 & Sultan Aji Muhammad Sulaiman Sepinggan Airport & Balikpapan \\
\hline 5 & Frans Kaisiepo Airport & Biak \\
\hline 6 & Sam Ratulangi Airport & Manado \\
\hline 7 & Syamsudin Noor Airport & Banjarmasin \\
\hline 8 & Ahmad Yani Airport & Semarang \\
\hline 9 & Adisutjipto Airport & Yogyakarta \\
\hline 10 & Adi Soemarmo Airport & Surakarta \\
\hline 11 & Internasional Lombok Airport & Central Lombok \\
\hline 12 & Pattimura Airport & Ambon \\
\hline 13 & El Tari Airport & Kupang \\
\hline
\end{tabular}

Eco-Airport. According to PT. Angkasa Pura, eco-airport is an eco-friendly airport utilizing the existing environmental sources with minimal environmental damage or disturbance. Meanwhile, according to the Airport Directorate, eco-airport is an airport that has been measured against the some components that potentially have an impact on the environment in order to create a healthy environment in the airport and its surroundings.

In order to realize the eco-airport concept at an airport, the Eco Airport Council is established and bring the duty of setting up environmental management targets consisting of 8 environmental elements (air, energy, noise/ vibration, water, soil, solid/ liquid waste, natural environment, and so on). The elements of the store atmosphere are the sound or noise level, the smell of the room, the physical appearance of the buildings, lighting, and temperature. Reviewing from eco-airport concept at Sultan Aji Muhammad Sulaiman Airport Balikpapan, the atmosphere elements applied to the eco-airport concept are:

- The noise level of the airport with the application of eco-airport concept;

- The smell of plants that are deliberately placed inside the airport; 
- The physical appearance of greenhouse building that enables natural light in the airport;

- Lighting in the airport is more dominant by utilizing solar energy to save more energy;

- Temperature is an air circulation system made with the application of eco-airport concept.

Mall Airport. According to Wikipedia, Mall is a kind of shopping center that is architecturally a closed building with a regulated temperature and has a path to have regular walk between the small shops facing each other. Berman and Joel (2007: 544) stated that one elements of store atmosphere include store layout that is the placement of space to fill the available floor area, classify the product to be offered, manage in-store traffic, set the required width of space, map the store room and arrange the offered products individually. Reviewing from mall-airport concept at Sultan Aji Muhammad Sulaiman Airport Balikpapan, the elements of store layout applied into mall-airport concept are:

- Selling space: a room used for displaying goods, interactions between sellers and consumers, demonstrations and others;

- Customer space: a room provided to improve consumer convenience;

- Traffic Flow: the traffic flow of mall airport allows the visitors to feel comfortable entering heading out the airport mall;

- Mapping of products within the airport mall so that the consumers can easily find the desired product.

Cultural Display of East Borneo. The blend of modern style and Borneo culture with Dayak nuance are so beautiful to see while visiting Sultan Aji Muhammad Sulaiman Airport Balikpapan. Despite the modern style of architecture, there are so many traditional nuances. There is the melody of Sape, a musical instrument of Dayak tribe. Each corner of the airport is decorated with distinctive dayak nuances, starting from local wildlife, traditional dances, the dazzling art of Dayak tribe, and even a portrait of Kutai Kartanegara King of Mulawarman which is displayed in the crowd spot at the airport, including the mall. All of them are presented through the displays that are scattered at the airport. By having the displays, it is expected that the visitors will be educated by the description of East Borneo culture.

According to Sopiah and Syihabuddin (2008: 238) Display is an attempt to arrange the goods that lead the buyers to be interested to look around and decide to buy the goods. According to Swastha and Ibnu (2009: 18), display is promoting the goods to consumers so that the consumers will easily observe them. Display has two purposes: to provide information to consumers and add to the store atmosphere.

Based on the statement of the experts about display, cultural display of East Borneo at Sultan Aji Muhammad Sulaiman Airport Balikpapan contains the following things:

- Arrangement of cultural display of East Borneo looks neat in its display;

- Visitors can easily observe cultural display of East Borneo through the displays that have been arranged.

- Cultural display of East Borneo educates consumers in terms of introduction of East Borneo culture.

- The creation of a unique airport atmosphere with cultural display of East Borneo.

Visitor Satisfaction. Satisfaction is the response of consumers related to the fulfillment of needs, (Žabkar et al., 2010). Satisfaction is an assessment of the characteristics or features of the product or service, or the product itself, which provides the level of consumer satisfaction related to the fulfillment of consumer consumption needs. The attribute forming the satisfaction consists of: 1) the suitability of expectations which is the level of suitability between the performance of the product which is expected and perceived by the customer, including the product or the service and also the available facilities; 2) the willingness of another visit which is the willingness of consumers to have another visit; 3 ) another recommendation which is the willingness of the consumers to recommend the products or services they just consumed to their close relatives (Yen, 2005).

Based on the statement of the experts, visitor satisfaction of East Borneo at Sultan Aji Muhammad Sulaiman Airport Balikpapan contains the following things: 
- The service at Sultan Aji Muhammad Sulaiman Airport Balikpapan is good;

- The facilities at Sultan Aji Muhammad Sulaiman Airport Balikpapan are adequate;

- The desire of the visitors to have another visit at Sultan Aji Muhammad Sulaiman Airport Balikpapan;

- The willingness of visitors to recommend the uniqueness of Sultan Aji Muhammad Sulaiman Airport Balikpapan.

Hypotheses Development:

Eco-airport concept on visitor satisfaction. Consumer satisfaction factors are the situation experienced by consumers and may trigger emotional condition of the consumer. According to Levy and Weits, one of the factors that can influence consumer emotional condition is to create a marketing atmosphere or so-called store atmosphere. The atmosphere focuses on the design environment through visual communication, lighting, color, music, and smells to stimulate the customer's perceptual and emotional response and ultimately affect the purchasing behavior. Eco-airport concept at Sultan Aji Muhammad Sulaiman Airport is applied into the atmosphere of the airport including greenhouse-based buildings, the dominant lighting of the sun, and the atmosphere of green environment. Netti and Aditya, in 2015, conducted a research entitled "The Influence Store Atmosphere on Consumer Satisfaction at Roemah Coffee Bandung". The results showed that store atmosphere had a significant influence on consumer satisfaction. Based on theoretical and empirical perspectives, the hypothesis can be drawn as follows:

$\mathrm{H} 1$ : Eco-airport concept has a positive and significant influence on visitor satisfaction.

Mall-airport concept on visitor satisfaction. Triyono (2006: 16) argued that layout is part of the retail mix which is included in the concept of place where the layout or presentation or display of goods (merchandise) is in the store. The presentation or display refers at least to traffic flow or customer traffic, location and the number of departments of goods to be sold, the width and location of the customer service counter, the product storage area, and the atmosphere around the store. In selecting a merchant, each consumer evaluates four key factors before making a decision, including: location, choices of goods, price, and shopping experience. Mall-airport concept at Sultan Aji Muhammad Sulaiman Airport is applied to the store layout including selling space, customer space, traffic flow, and product mapping. Supriyani and Sahala, in 2013, conducted a research entitled "The Influence of Layout on Retail Customer Satisfaction". The results showed that the layout influenced consumer satisfaction. Based on theoretical and empirical perspectives, the hypothesis can be drawn as follows:

$\mathrm{H} 2$ : Mall-airport concept has a positive and significant influence on visitor satisfaction.

The concept of cultural display of East Borneo on visitor satisfaction. Display may influence customer satisfaction: "Display has great appeal to a buyer who is driven to make a purchase or to a buyer who does not have any plan at the previous purchase, and finally get a sense of satisfaction in their purchase". Fransisca et al., in 2013, examined an interior display in a restaurant at Surabaya under the title of "Influence Store Layout, Interior Display, Human Variable on Customer Shopping Orientation at Dewandaru Restaurant Surabaya". Interior display of restaurant was very unique by displaying the values of Javanese traditional culture and the results showed that the interior display with the theme of culture had a significant influence on consumer purchasing decision.

The interior display of Sultan Aji Muhammad Sulaiman Airport also applies the promotional theme of East Borneo culture. It can be seen from the displays decorating with with distinctive Dayak nuance, starting from local animals, the dazzling traditional dances and arts of Dayak tribe, and also a portrait of Kutai Kartanegara King of Mulawarman displayed in mall-airport spot. A research published in 2017 entitled "Analysis of the Influence of Product Display and Store Atmosphere on Customer Satisfaction (Survey in Yogya Supermarket Tasikmalaya Branch)", explained that display was very influential to customer satisfaction. Based on theoretical and empirical perspectives, the hypothesis can be drawn as follows:

H3: Cultural display of East Borneo has a positive and significant influence on visitor satisfaction. 


\section{CONCEPTUAL FRAMEWORK}

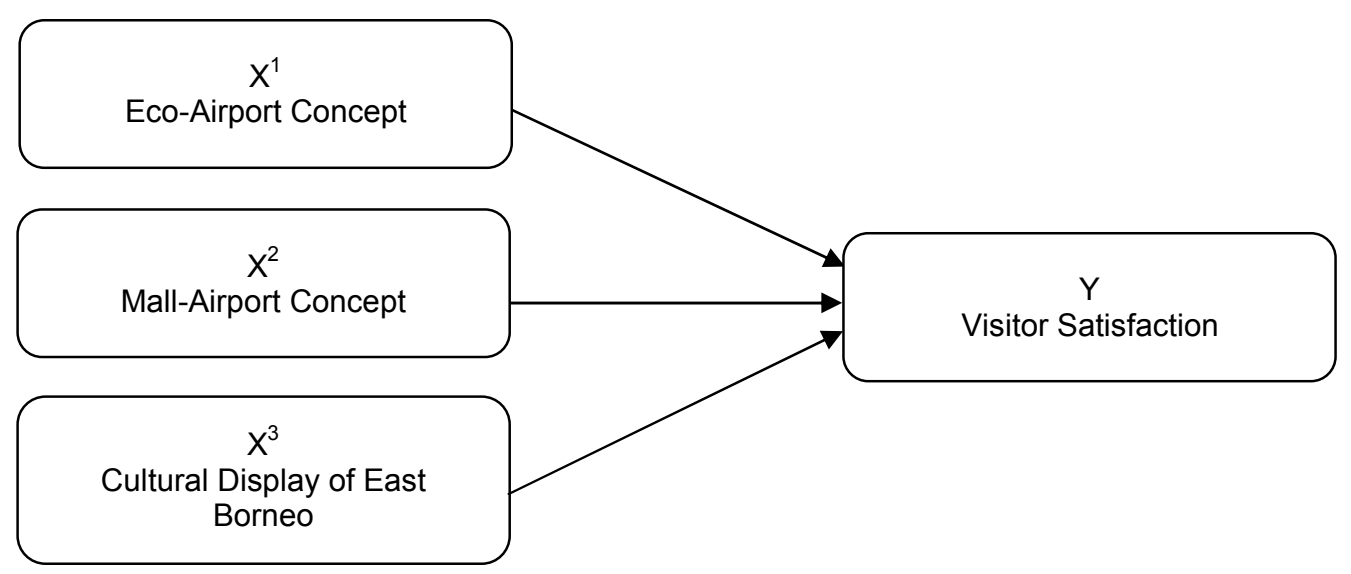

Figure 1 - Conceptual Framework

\section{METHODS OF RESEARCH}

This research is an explanatory research in which knowing and explaining the influence between variables that aimed to test a theory or hypothesis in order to strengthen or reject a theory or empirical study which have been conducted before and then it is continued with hypothesis testing. Therefore, this research explained the causal relationship among variables. This research used survey technique by spreading questionnaire consisting values based on Likert scale by using interval value 1-5. Variables of the research consisted of three independent variables $(X)$ : Eco-Airport concept $\left(X^{1}\right)$, Mall-Airport concept $\left(X^{2}\right)$, Cultural Display of East Borneo $\left(\mathrm{X}^{3}\right)$, and one dependent variable $(\mathrm{Y})$ : visitor satisfaction.

Data sampling was conducted by using purposive sampling technique that was based on consideration of research or based on the desired elements or based on certain criteria, Sugiyono (2009: 125). The population of the research is unknown. Therefore, to determine the number of samples Roscoe formula was used. Sample criteria of the research were the people who visited Sultan Aji Muhammad Sulaiman Airport Balikpapan, either for a walk or for business departure. The samples were many as 40 people.

The analytical tool of the research was Smart-PLS 3.0 and the method of the research was path analysis method. According to Ghozali (2015:67), path analysis method consists of two models: structural model (inner model), a model that explains the relationship between latent variables and measurement model (outer model), a model that explains the indicators with latent variables. Before conducting the second test phase of the model, estimation stage was conducted with the iteration process to achieve convergent conditions in which each indicator of latent variable had the loading factor $<0.05$.

\section{RESULTS AND DISCUSSION}

Estimation Stage. Based on the iteration process, indicator X2.4 was $<0.50$ in which it was only 0.418 so it should be eliminated.

The indicators of Eco-Airport concept consisting of noise level (x1.1), plant aroma inside the airport (x1.2), physical display of greenhouse buildings (x1.3), and lighting in the airport with solar utilization (x1.4) had met the convergent condition in which having the value of $>0.50$. Therefore, it can be concluded that all indicators are feasible to measure the variable of Eco-Airport concept. The indicators of Mall-Airport concept consisting of selling space (x2.1), costumer space (x2.2), and traffic flow (x2.3), had met the convergent condition in which having the value of $>0.50$. Therefore, it can be concluded that all indicators are feasible to measure the variable of Mall-Airport concept. 
Table 2 - Loading factor of each construct

\begin{tabular}{|c|c|c|c|}
\hline Variable & Construct & $\begin{array}{l}\text { Loading } \\
\text { Factor }\end{array}$ & Description \\
\hline \multirow{4}{*}{ Eco-Airport Concept } & Noise level (X1.1) & 0.699 & $>0.50$ \\
\hline & Plant aroma inside the airport (X1.2) & 0.720 & $>0,50$ \\
\hline & Physical display of greenhouse buildings (X1.3) & 0.572 & $>0.50$ \\
\hline & Lighting in the airport with solar utilization (X1.4) & 0.812 & $>0.50$ \\
\hline \multirow{4}{*}{ Mall-Airport Concept } & Selling space $(X 2.1)$ & 0.771 & $>0.50$ \\
\hline & Customer space (X2.2) & 0.631 & $>0.50$ \\
\hline & Traffic flow (X2.3) & 0.880 & $>0.50$ \\
\hline & Product mapping (X2.4) & 0.418 & elimination \\
\hline \multirow{4}{*}{$\begin{array}{l}\text { Cultural Display of } \\
\text { East Borneo }\end{array}$} & Display Arrangement (X3.1) & 0.604 & $>0.50$ \\
\hline & Ease in observing display (X3.2) & 0.537 & $>0.50$ \\
\hline & Cultural display of East Borneo educates visitors (X3.3) & 0.917 & $>0.50$ \\
\hline & $\begin{array}{l}\text { The existence of the displays creates a unique airport } \\
\text { atmosphere (X3.4) }\end{array}$ & 0.662 & $>0.50$ \\
\hline \multirow{4}{*}{ Visitor Satisfaction } & Good service (Y.1) & 0.811 & $>0.50$ \\
\hline & Adequate facilities (Y.2) & 0.849 & $>0.50$ \\
\hline & Willingness to have another visit to the airport (Y.3) & 0.581 & $>0.50$ \\
\hline & $\begin{array}{l}\text { Willingness of the visitors to recommend the uniqueness of } \\
\text { the airport to their relatives }(Y .4)\end{array}$ & 0.775 & $>0.50$ \\
\hline
\end{tabular}

Source: Smart-PLS 3.0

Table 3 - Loading factor of each construct at the second iteration

\begin{tabular}{|c|c|c|c|}
\hline Variable & Construct & $\begin{array}{l}\text { Loading } \\
\text { Factor }\end{array}$ & Description \\
\hline \multirow{4}{*}{ Eco-Airport Concept } & Noise level (X1.1) & 0.779 & $>0.50$ \\
\hline & Plant aroma inside the airport (X1.2) & 0.622 & $>0.50$ \\
\hline & Physical display of greenhouse buildings (X1.3) & 0.582 & $>0.50$ \\
\hline & Lighting in the airport with solar utilization (X1.4) & 0.711 & $>0.50$ \\
\hline \multirow{3}{*}{ Mall-Airport Concept } & Selling space (X2.1) & 0.801 & $>0.50$ \\
\hline & Customer space (X2.2) & 0.601 & $>0.50$ \\
\hline & Traffic flow (X2.3) & 0.851 & $>0.50$ \\
\hline \multirow{4}{*}{$\begin{array}{l}\text { Cultural Display of } \\
\text { East Borneo }\end{array}$} & Display Arrangement (X3.1) & 0.625 & $>0.50$ \\
\hline & Ease in observing display (X3.2) & 0.533 & $>0.50$ \\
\hline & Cultural display of East Borneo educates visitors (X3.3) & 0.927 & $>0.50$ \\
\hline & $\begin{array}{l}\text { The existence of the displays creates a unique airport } \\
\text { atmosphere (X3.4) }\end{array}$ & 0.692 & $>0.50$ \\
\hline \multirow{4}{*}{ Visitor Satisfaction } & Good service (Y.1) & 0.831 & $>0.50$ \\
\hline & Adequate facilities (Y.2) & 0.829 & $>0.50$ \\
\hline & Willingness to have another visit to the airport (Y.3) & 0.697 & $>0.50$ \\
\hline & $\begin{array}{l}\text { Willingness of the visitors to recommend the uniqueness of } \\
\text { the airport to their relatives }(Y .4)\end{array}$ & 0.750 & $>0.50$ \\
\hline
\end{tabular}

Source : Smart-PLS 3.0

The indicators of cultural display of East Borneo consisting of display arrangement (x3.1), ease in observing display (x3.2), cultural display of east borneo educates visitors (x3.3), and the existence of the displays creates a unique airport atmosphere (x3.4) had met the convergent condition in which having the value of $>0.50$. Therefore, it can be concluded that all indicators are feasible to measure the variable of cultural display of East Borneo.

The indicators of visitor satisfaction consisting of good service (Y.1), adequate facilities (y.2), willingness to have another visit to the airport (y.3), and willingness of the visitors to recommend the uniqueness of the airport to their relatives ( $y .4)$ had met the convergent condition in which having the value of $>0.50$. Therefore, it can be concluded that all indicators are feasible to measure the variable of visitor satisfaction. Based on the result of the second iteration, the indicators of all latent variables had been qualified for convergent condition in which having the value of $>0.50$. Therefore, the research could be continued to analyze the outer model and the inner model. 
Testing of Measurement Model (Outer Model) and Structural Model (Inner Model):

Table 4 - Model testing

\begin{tabular}{|c|c|c|c|c|c|}
\hline Variables/ Indicators & $\begin{array}{l}\text { Outer } \\
\text { Loading }\end{array}$ & T-statistic & $\begin{array}{l}\text { Composite } \\
\text { Reliability }\end{array}$ & AVE & $\begin{array}{l}\text { AVE } \\
\text { Root }\end{array}$ \\
\hline A. Eco-Airport Concept (X1) & & & 0.952 & 0.794 & 0.891 \\
\hline Noise level (X1.1) & 0.756 & 67.1 & & & \\
\hline Plant aroma inside the airport (X1.2) & 0.822 & 73.581 & & & \\
\hline Physical display of greenhouse buildings (X1.3) & 0.859 & 23.091 & & & \\
\hline Lighting in the airport with solar utilization (X1.4) & 0.874 & 42.8 & & & \\
\hline B. Mall-Airport Concept (X2) & & & 0.952 & 0.797 & 0.893 \\
\hline Selling space $(X 2.1)$ & 0.855 & 33.614 & & & \\
\hline Customer space (X2.2) & 0.935 & 77.01 & & & \\
\hline Traffic flow (X2.3) & 0.771 & 42.16 & & & \\
\hline C. Cultural Display of East Borneo (X3) & & & 0.921 & 0.701 & 0.837 \\
\hline Display Arrangement (X3.1) & 0.877 & 55.96 & & & \\
\hline Ease in observing display (X3.2) & 0.883 & 55.7 & & & \\
\hline Cultural display of East Borneo educates visitors (X3.3) & 0.952 & 89.31 & & & \\
\hline $\begin{array}{l}\text { The existence of the displays creates a unique airport } \\
\text { atmosphere }(\mathrm{X} 3.4)\end{array}$ & 0.832 & 20.1 & & & \\
\hline D. Visitor Satisfaction (Y) & & & 0.933 & 0.736 & 0.857 \\
\hline Good service (Y.1) & 0.881 & 23.91 & & & \\
\hline Adequate facilities (Y.2) & 0.803 & 42.1 & & & \\
\hline Willingness to have another visit to the airport (Y.3) & 0.869 & 69.437 & & & \\
\hline $\begin{array}{l}\text { Willingness of the visitors to recommend the uniqueness } \\
\text { of the airport to their relatives }(Y .4)\end{array}$ & 0.882 & 77.17 & & & \\
\hline
\end{tabular}

Source: Smart-PLS 3.0

Table 5 - R-Square

\begin{tabular}{lcc}
\hline & Variable & R-Square \\
\hline Eco-Airport Concept (X1) & & \\
Mall-Airport Concept (X2) & & 0.783 \\
Cultural Display of East Borneo (X3) & & \\
Customer Satisfaction (Y) & & 0.78 \\
\hline
\end{tabular}

Source: Smart-PLS 3.0

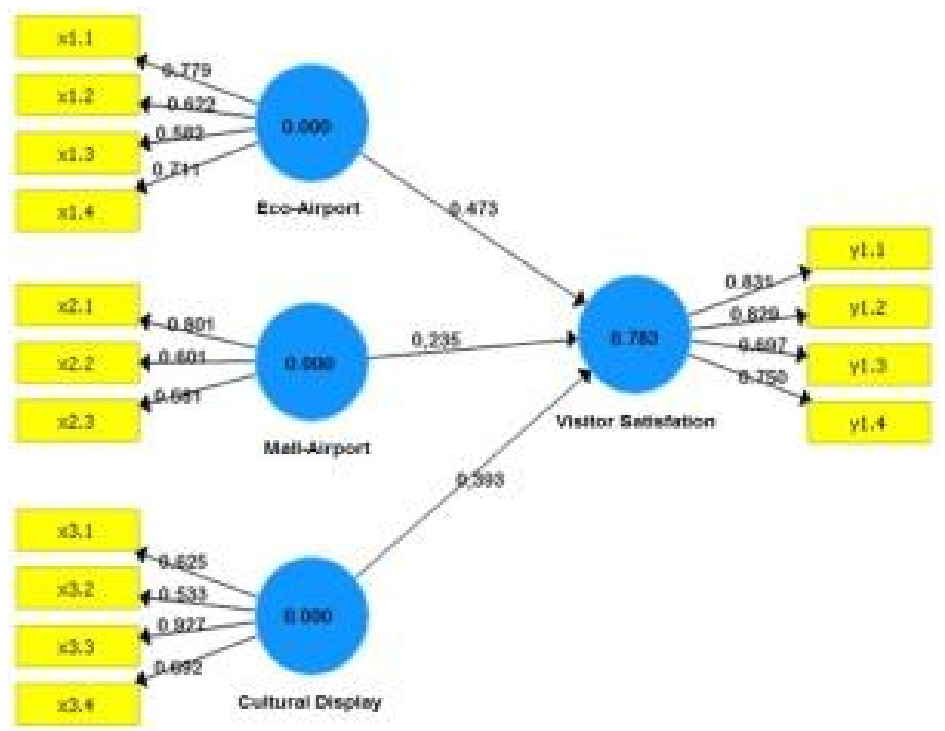

Figure 2 - Structural model (Source: Smart-PLS 3.0)

Based on the overall results, the indicators of each variable had outer loading value greater than 0.5 and $t$-statistic value greater than the t-critical value (1.96) which meant that each valid and significant indicator explained each variable. The four variables had AVE value higher than 0.50 and all variables had AVE root value higher than the correlation coefficient between one variable with another. Thus, it can be concluded that the data had good discriminant validity. The values of composite reliability of all constructs were more than 
0.60 so it had met the reliable criteria. Based on the overall evaluation results of convergent, discriminant validity and composite reliability that had been described above, it can be concluded that the indicators as a measure of latent variables were valid and reliable.

The result of PLS analysis was shown in Figure 1. This result was based on the model showing that Eco-Airport and Mall-Airport concepts and cultural display of East Borneo had positive influence on visitor satisfaction.

Data from the figure conclude as follows:

- Hypothesis 1 stated that Eco-Airport concept has positive influence on visitor satisfaction at Sultan Aji Muhammad Sulaiman Airport Balikpapan is accepted.

- Hypothesis 2 stated that Mall-Airport concept has positive influence on visitor satisfaction at Sultan Aji Muhammad Sulaiman Airport Balikpapan is accepted.

- Hypothesis 3 stated that cultural display of East Borneo has positive influence on visitor satisfaction at Sultan Aji Muhammad Sulaiman Airport Balikpapan is accepted.

\section{CONCLUSION AND SUGGESTIONS}

Eco-Airport concept has positive influence on visitor satisfaction at Sultan Aji Muhammad Sulaiman Airport Balikpapan. It means that the better the Eco-Airport concept, the higher the visitor satisfaction. Lighting of the airport, with the use of the solar system in the application of Eco-Airport concept is the most powerful indicator to explain visitor satisfaction at Sultan Aji Muhammad Sulaiman Airport Balikpapan. Author's suggestion is that the airport management should maintain the existence of the iconic greenhouse buildings, so that the perception of Eco-Airport concept coming up to the visitor is utilizing the solar system as the lighting through the transparent glass wall in order to increase visitor satisfaction. In addition, the indicator of noise levels and aroma of the plants in the airport should be more noticed in order to increase the sense of visitor satisfaction.

Mall-Airport concept has positive influence on visitor satisfaction at Sultan Aji Muhammad Sulaiman Airport Balikpapan. It means that the better the Mall-Airport concept, the higher the visitor satisfaction. Customer space in the application of the Mall-Airport concept is the most powerful indicator to explain visitor satisfaction at Sultan Aji Muhammad Sulaiman Airport Balikpapan. Author's suggestion is that the airport management should provide consumer space either for shopping or just taking a walk by continuing to make improvements in the lounge or with consumer space. In addition, the indicators of selling space and traffic flow should be more noticed in order to increase the sense of visitor satisfaction.

Cultural display of East Borneo has positive influence on visitor satisfaction at Sultan Aji Muhammad Sulaiman Airport Balikpapan. It means that the more unique the cultural display of East Borneo, the higher the visitor satisfaction. The educating cultural display of East Borneo is the most powerful indicator to explain the visitor satisfaction at Sultan Aji Muhammad Sulaiman Airport Balikpapan. Author's suggestion is that the airport management should explore the cultural diversity of East Borneo and provide special space for promotional cultural displays of East Borneo to create a unique impression for visitor satisfaction. In addition, the indicators of display setting and ease in observing the display should be more noticed in order to increase the sense of visitor satisfaction.

Based on the observation, the visitors gave feedback value from the perceived satisfaction. It can be seen from the high indicator of satisfaction to recommend their relatives about Sultan Aji Muhammad Sulaiman Airport Balikpapan. Author's suggestion is that the management keeps providing good service, adequate facilities, and impression that make the visitors feel at home and stay longer at the airport. Therefore, it create the intention to visit have another visit and the intention to recommend the airport to their relatives.

Finally, the most important suggestion is that the management of Angkasa Pura should consider the innovation of Eco-Airport and Mall-Airport concepts and cultural display of East Borneo in order to create an effective marketing process to their airports. Moreover, the management of other places, in the restaurant, transportation bases or anywhere, should give more attention to the design of the building to get higher visitor satisfaction. 


\section{REFERENCES}

1. Berman, B., Joel R.E. (2007), Retail Management. New Jersey: Prentice Hall.

2. Buchari, A. (2007), Manajemen Pemasaran dan Pemasaran Jasa.Bandung : Alfabeta.

3. Caves, R. E. (1997). European airline networks and their implications for airport planning. Transport reviews, 17(2), 121-144.

4. De Neufville, R. (2016), Airport systems planning and design. Air Transport Management: An International Perspective, 61.

5. Grewal, D., Baker, J., Levy, M., Voss, G.B. (2003), The effects of wait expectations and store atmosphere evaluations on patronage intentions in service-intensive retail stores. Journal of retailing, 79(4), 259-268.

6. Hansemark, O.C., Albinsson, M. (2004), Customer satisfaction and retention: the experiences of individual employees. Managing Service Quality: An International Journal, 14(1), 40-57.

7. Kazda, A., Caves, R.E. (Eds.). (2010), Airport design and operation. Emerald

8. Savitri, N.D. (2017), Percepatan Pembangunan Infrastruktur Pada Bandar Udara Guna Meningkatkan Rasio Pendapatan Asli Daerah Di Wilayah Kalimantan Timur Khususnya Kota Balikpapan. ISEI ECONOMIC REVIEW, 1(1), 1-4.

9. Sopiah, Syihabuddin. (2008), Bisnis Ritel. Yogyakarta : Andi.

10. Sugiyono. (2009), Metode Penelitian Kuantitatif, Kualitatif dan R\&D. Bandung : Alfabeta.

11. Swastha, Ibnu. (2009), Pengantar Bisnis Modern, Yogyakarta.

12. Triyono, S. (2006), Sukses Terpadu Bisnis Ritel. Jakarta: PT. Elex Media Komputindo.

13. Woodruff, R.B., Gardial, S. (1996), Know your customer: New approaches to understanding customer value and satisfaction. New York: John Wiley \& Sons.

14. Yen, H.R. (2005), An attribute-based model of quality satisfaction for internet self-service technology. The Service Industries Journal, 25(5), 641-659.

15. Žabkar, V., Brenčič, M.M., Dmitrović, T. (2010), Modelling perceived quality, visitor satisfaction and behavioural intentions at the destination level. Tourism management, 31(4), 537-546. 